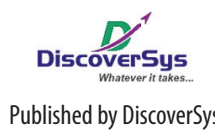

Published by DiscoverSys

\section{Perceived importance of structural factors are associated with the selection of primary care by national health insurance participants}

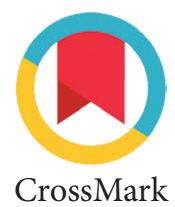

\author{
Putu Nitya Nirmala, ${ }^{1 *}$ Pande Putu Januraga, ${ }^{2}$ Putu Ayu Indrayathi ${ }^{2}$
}

\title{
ABSTRACT
}

Background and purpose: Primary care are the entry point for health services in an insurance-based health financing system, including the National Health Insurance Program or Jaminan Kesehatan Nasional $(J K N)$ in Indonesia. This study aims to understand the association between structural factors in health service management with primary care selection among $J K N$ participants.

Methods: The study used a cross sectional analytic design, conducted with 273 self-paid JKN participants in Denpasar as respondents. The samples were selected using multistage random sampling. Data was collected from April to May 2018 with interviews using a questionnaire covering the characteristics of respondents and perceptions on the importance of health care facilities, the capabilities of health providers, service distance, operational time, availability of drugs and medical equipment. Data analysis was carried out with multinomial logistic regression to determine the structural factors of health service management associated with the selection of primary care.
Results: Most respondents (65.9\%) chose private clinics, 21.3\% chose public health centres (PHCs) and $12.8 \%$ chose individual practicing physicians. Multivariate analysis showed that the variables which significantly associated with the selection of primary care among JKN participants were the perceived importance of the health care facilities at PHCs and private clinics, each with $A 0 R=7.83$ (95\%Cl: 2.72-22.54) and $A O R=7.18$ (95\% $\mathrm{Cl}: 2.76-18.68)$, the perceived importance of the capability of health workers in private clinics with AOR $=0.29(95 \% \mathrm{Cl}$ : $0.12-0.77)$, the perceived importance of health service time in private clinics with $A 0 R=2.67(95 \% \mathrm{Cl}: 1.05-6.74)$ and history of health services utilization at private clinics with $\mathrm{AOR}=4.51$ ( $95 \% \mathrm{Cl}: 1.86-10.96)$.

Conclusion: Structural factors are associated with the selection of primary care among JKN participants. Attention to the quality and quantity of structural factors in the management of health services is important to improve the equitable distribution of JKN membership in the registered primary care.

Keywords: structural factors, primary care selection, national health insurance

Cite This Article: Nirmala, P.N., Januraga, P.P., Indrayathi, P.A. 2019. Perceived importance of structural factors are associated with the selection of primary care by national health insurance participants. Public Health and Preventive Medicine Archive 7(2): 103-109. D0I:10.15562/phpma.v7i2.212

'Public Health Postgraduate Program, Faculty of Medicine, Udayana University

${ }^{2}$ Department of Public Health and Preventive Medicine, Faculty of Medicine, Udayana University

*Correspondence to: Putu Nitya Nirmala, Public Health Postgraduate Program, Faculty of Medicine, Udayana University nitya_nirmala@yahoo.com

\section{INTRODUCTION}

One of the milestones of health service reforms in Indonesia is the introduction of the National Health Insurance or called Jaminan Kesehatan Nasional $(J K N)$. This health insurance system encourages the delivery of managed care-based health services, where primary care function as the first contact of health services through promotive, preventive, curative and rehabilitative efforts. ${ }^{1}$ Based on these functions, primary care are expected to be able to provide comprehensive and quality health services to encourage improvement in the health status of JKN participants.

The selection of primary care is determined by the Health Insurance Administering Agency or called Badan Penyelenggara Jaminan Sosial (BPJS) based on the recommendation of the district or city health office, ${ }^{2}$ but in its implementation, there is an opportunity for JKN participants to choose their own primary care. This mechanism affect the health care services preferences of JKN participants, which has resulted in an imbalance number of participants between primary care. BPJS data in Denpasar in 2016 showed that 18 of the 119 primary care (16\%) experienced patient overload. There are clinics with 51,717 participants with a ratio of 1:10,000, while there are individual practicing doctors with a very small number of only two participants. ${ }^{3}$ Health facilities with high number of patients or unbalanced ratios have a tendency to bring about a decline in service quality, while primary care with a small number of participants will find it difficult to finance their health services. ${ }^{4} \mathrm{~A}$ balance is required between the number of registered participants, operational adequacy and service quality through equal distribution of participant ratios throughout the primary care. ${ }^{4}$

Other studies related to the selection of health service providers among patients in various countries show that structural factors in the management of health services such as health facilities, the capability of health providers, distance to health facilities, operational time for health services, availability of drugs and medical equipment are associated with selection of health services. ${ }^{5-7}$ 
Other studies documented that factors related to health service selection included the availability of facilities, good relationship with patients, level of education, age and severe diseases. ${ }^{6,8}$ Furthermore, structural factors are reported as the main components that must be considered by health providers in delivering high quality health services to the public. ${ }^{5}$ Based on our knowledge, there is no similar study in the context of primary care selection in Indonesia.

This study aims to understand the association between perceived structural factors of health service management with primary care selection by JKN participants.

\section{METHODS}

A cross-sectional survey was conducted from April to May 2018 among 273 JKN participants in Denpasar City with $77 \%$ membership coverage in January 2018. Sample size was calculated based on hypothesis tests for two population proportions. The anticipated values of the population proportions P1 was estimated using data from previous study in which there were $61.9 \%$ of the respondents perceived health center had good facilities, ${ }^{2}$ meanwhile the P2 was assigned for 0.5 . The significance value was 0.05 with $Z_{\alpha}=1.96$ and $Z_{\beta}=0.842$ and power of the test was $80 \%$.

Participants were selected using multistage random sampling. At the first stage, one district was selected randomly from the four districts in Denpasar. The selected district was West Denpasar which consists of 11 villages. From each village, two neighbourhoods or called banjar were selected by simple random sampling resulted a sample of 22 banjar. In the final stage, 273 respondents were chosen in 22 banjar with convenience approach by visiting each household starting from those closest to the banjar hall, followed by the next household until the number of samples was met. Eligible respondents are the self-paid JKN members, the reason for this selection was the ability of self-paid members to select primary care provider based on their own preferences. The interviews were conducted at the respondents' house and family head or family members who were met at home were interviewed.

Before the interview the respondents were given time to read and sign the informed consent. The first author conducted an interview with a questionnaire covering the primary care preferences, respondents' perceptions on the structural factors of health service management which consisted of health services facilities, the capability of health providers, distance to health services, operational time of health services and availability of drugs and medical equipment. These variables were measured using several questions with a Likert scale option ranging from very disagree (1) to very agree (5). Each variable then grouped into two categories which were "important" if the score was the same with or higher than mean score and "not important" if the score was lower than the mean score. In addition, respondents' characteristics were also collected including history of examinations by the doctor at the primary care, JKN class, gender, education, age and the history of chronic diseases. Descriptive data analysis was conducted to determine the proportion of primary care types selected by respondents. Multinomial logistic regression was performed to examine the association between structural factors in health care management with primary care selection. All independent and socio-demographic variables, including those statistically not significant in bivariate analysis, were included in the multivariate model with a consideration that those variables available in the literature.

This study has been approved by the Ethics Committee of the Faculty of Medicine, Udayana University/Sanglah General Hospital, Denpasar on 17 April 2018.

\section{RESULTS}

Table 1 presents the respondents' characteristics by age, gender, education, JKN class, medical and disease history. Most respondents were $>44$ years old, almost the same proportion by gender, most had an education of high school and above, about half were JKN second-class participants, most had never had an examination at primary care and had no history of severe or chronic illness.

Table 2 shows that $21.3 \%$ respondents chose PHCs, $65.9 \%$ chose private clinics, and $12.8 \%$ chose private physicians. It is shown that respondents who chose $\mathrm{PHCs}$ were mostly $>44$ years old (53.4\%), male (56.9\%), high school educated (53.4\%), had second class JKN membership (39.7\%), had a history of examinations (56.9\%) and did not have a history of chronic disease (84.5\%). Respondents who chose private clinics were mostly $>44$ years old $(43.9 \%)$, female (52.8\%), high school educated (51.1\%), had second class JKN membership (43.9\%), had no history of examinations (78.9\%) and had no history of chronic disease (84.4\%). While respondents who chose individual practicing physicians were mostly $>44$ years (45.7\%), female (62.9\%), high school educated (57.1\%), had a second class JKN membership (65.7\%), had a history of health services utilization $(57.1 \%)$ and did not have history of chronic disease (88.6\%).

Table 3 presents respondents' distribution based on primary care selection and their perceived 
Table 1 Respondent characteristics

\begin{tabular}{|c|c|c|}
\hline Characteristics & $\mathbf{n}$ & $\%$ \\
\hline \multicolumn{3}{|l|}{ Age (years) } \\
\hline $17-29$ & 49 & 17.9 \\
\hline $30-44$ & 98 & 35.9 \\
\hline$>44$ & 126 & 46.2 \\
\hline \multicolumn{3}{|l|}{ Gender } \\
\hline Female & 142 & 52.0 \\
\hline Male & 131 & 48.0 \\
\hline \multicolumn{3}{|l|}{ Education } \\
\hline Diploma and college & 61 & 22.3 \\
\hline Senior high & 143 & 52.4 \\
\hline Junior high & 69 & 25.3 \\
\hline \multicolumn{3}{|l|}{ JKN class } \\
\hline 1 & 80 & 29.3 \\
\hline 2 & 125 & 45.8 \\
\hline 3 & 68 & 24.9 \\
\hline \multicolumn{3}{|c|}{ History of health services utilization } \\
\hline Yes & 91 & 33.3 \\
\hline No & 182 & 66.7 \\
\hline \multicolumn{3}{|l|}{ History of chronic illness } \\
\hline Yes & 41 & 15.0 \\
\hline No & 232 & 85.0 \\
\hline Total & 273 & 100.0 \\
\hline
\end{tabular}

Table 2 Characteristics of respondents based on primary care selection

\begin{tabular}{lccc}
\hline & \multicolumn{3}{c}{ Primary care type } \\
\cline { 2 - 4 } Characteristics & PHCs & Private clinics & Individual practicing physicians \\
\hline Age (years) & $\mathrm{n}(\%)$ & $\mathrm{n}(\%)$ & $\mathrm{n}(\%)$ \\
$17-29$ & $7(12.1)$ & $33(18.3)$ & $9(25.7)$ \\
$30-44$ & $20(34.5)$ & $68(37.8)$ & $10(28.6)$ \\
$>44$ & $31(53.4)$ & $79(43.9)$ & $16(45.7)$ \\
Gender & & & $22(62.9)$ \\
Female & $25(43.1)$ & $95(52.8)$ & $13(37.1)$ \\
Male & $33(56.9)$ & $85(47.2)$ & $8(22.9)$ \\
Education & & & $20(57.1)$ \\
Diploma and college & $14(24.1)$ & $39(21.7)$ & $7(20.0)$ \\
Senior high & $31(53.4)$ & $92(51.1)$ & \\
Junior high & $13(22.4)$ & $49(27.2)$ & $8(22.9)$ \\
JKN class & & & $23(65.7)$ \\
1 & $18(31.0)$ & $54(30.0)$ & $4(11.4)$ \\
2 & $23(39.7)$ & $79(43.9)$ & $47(26.1)$ \\
3 & $17(29.3)$ & &
\end{tabular}


Table 2 Continue

Primary care type

\begin{tabular}{lccc}
\cline { 2 - 3 } Characteristics & PHCs & Private clinics & Individual practicing physicians \\
\hline $\begin{array}{l}\text { History of health services } \\
\text { utilization } \\
\text { Yes }\end{array}$ & & \\
No & $33(56.9)$ & $38(21.1)$ & $20(57.1)$ \\
History of chronic illness & $25(43.1)$ & $142(78.9)$ & $15(42.9)$ \\
Yes & $9(15.5)$ & $28(15.6)$ & $4(11.4)$ \\
No & $49(84.5)$ & $152(84.4)$ & $31(88.6)$ \\
Total & $58(21.3)$ & $180(65.9)$ & $35(12.8)$ \\
\hline
\end{tabular}

Table 3 The proportion of respondents by primary care selection and perceptions of health service management

\begin{tabular}{|c|c|c|c|}
\hline \multirow{3}{*}{$\begin{array}{l}\text { Perceptions of structural } \\
\text { management }\end{array}$} & \multicolumn{3}{|c|}{ Selected primary care } \\
\hline & PHCs & Private clinics & Individual practicing physicians \\
\hline & n (\%) & n (\%) & n (\%) \\
\hline \multicolumn{4}{|l|}{ Health service facilities } \\
\hline Important & $39(67.2)$ & $134(74.4)$ & $9(25.7)$ \\
\hline Less important & $19(32.8)$ & $46(25.6)$ & $26(74.3)$ \\
\hline \multicolumn{4}{|c|}{ Capability of health providers } \\
\hline Important & $20(34.5)$ & $65(36.1)$ & $16(45.7)$ \\
\hline Less important & $38(65.5)$ & $115(63.9)$ & $19(54.3)$ \\
\hline \multicolumn{4}{|l|}{ Distance to health services } \\
\hline Important & $41(70.7)$ & $123(68.3)$ & $18(51.4)$ \\
\hline Less important & $17(29.3)$ & $57(31.7)$ & $17(48.6)$ \\
\hline \multicolumn{4}{|c|}{ Operational time of health services } \\
\hline Important & $31(53.4)$ & $143(79.4)$ & $17(48.6)$ \\
\hline Less important & $27(46.6)$ & $37(20.6)$ & $18(51.4)$ \\
\hline \multicolumn{4}{|c|}{$\begin{array}{l}\text { Availability of drugs and medical } \\
\text { equipment }\end{array}$} \\
\hline Important & $19(32.8)$ & $74(41.1)$ & $11(31.4)$ \\
\hline Less important & $39(67.2)$ & $106(58.9)$ & $24(68.6)$ \\
\hline Total & $58(21.3)$ & $180(65.9)$ & $35(12.8)$ \\
\hline
\end{tabular}

Table 4 Adjusted OR of respondent characteristics and perception of structural management of health services

\begin{tabular}{|c|c|c|c|c|c|}
\hline \multirow[b]{3}{*}{ Variables } & \multicolumn{5}{|c|}{ Selected primary care } \\
\hline & \multicolumn{2}{|c|}{ PHCs } & \multicolumn{2}{|c|}{ Private clinics } & \multirow{2}{*}{$\begin{array}{c}\text { Individual practicing } \\
\text { physicians (Ref) }\end{array}$} \\
\hline & AOR & $95 \% \mathrm{Cl}$ & AOR & $95 \% \mathrm{Cl}$ & \\
\hline \multicolumn{6}{|c|}{ History of health services utilization } \\
\hline Yes & 0.73 & $0.28-1.96$ & 4.51 & $1.86-10.96$ & 1 (Ref) \\
\hline No & 1 (Ref) & 1 (Ref) & 1 (Ref) & 1 (Ref) & \\
\hline \multicolumn{6}{|c|}{ Health service facilities } \\
\hline Important & 7.83 & $2.72-22.54$ & 7.18 & $2.76-18.68$ & 1 (Ref) \\
\hline Less important & 1 (Ref) & 1 (Ref) & 1 (Ref) & 1 (Ref) & \\
\hline
\end{tabular}




\begin{tabular}{|c|c|c|c|c|c|}
\hline \multirow[b]{3}{*}{ Variables } & \multicolumn{5}{|c|}{ Selected primary care } \\
\hline & \multicolumn{2}{|c|}{ PHCs } & \multicolumn{2}{|c|}{ Private clinics } & \multirow{2}{*}{$\begin{array}{l}\text { Individual practicing } \\
\text { physicians (Ref) }\end{array}$} \\
\hline & AOR & $95 \% \mathrm{Cl}$ & AOR & $95 \% \mathrm{Cl}$ & \\
\hline \multicolumn{6}{|c|}{ Capability of health providers } \\
\hline Important & 0.4 & $0.14-1.13$ & 0.29 & $0.12-0.77$ & 1 (Ref) \\
\hline Less important & 1 (Ref) & 1 (Ref) & 1 (Ref) & 1 (Ref) & \\
\hline \multicolumn{6}{|l|}{ Operational time } \\
\hline Important & 0.625 & $0.23-1.71$ & 2.67 & $1.05-6.74$ & 1 (Ref) \\
\hline Less important & 1 (Ref) & 1 (Ref) & 1 (Ref) & 1 (Ref) & \\
\hline
\end{tabular}

importance of health care facilities, capability of health providers, distance to health services, operational time of health services, availability of medicines and medical equipment. It is evident that respondents who chose the PHC mostly considered health service facilities (67.2\%) and service distance (70.7\%) are important. Respondents who chose private clinics mostly considered availability of health care facilities (74.4\%) and operational time (79.4\%) are important. Whereas most respondents who chose individual practicing physicians (51.4\%) considered distance to health services is important.

Table 4 presents the results of a multivariate analysis and it is evident that the structural factor of health service management is significantly associated with the selection of primary care as well as the perceived importance of health service facilities at the private health centers and clinics with each $\mathrm{AOR}=7.83$ (95\%CI: 2.72-22.54) and $\mathrm{AOR}=7.18$ (95\%CI: 2.76-18.68), perceived importance of the capability of health providers in private clinics with $\mathrm{AOR}=0.29$ (95\%CI: 0.12-0.77), perceived importance of operational time in private clinics with $\mathrm{AOR}=2.67$ (95\%CI: 1.05-6.74). In addition, this was also significantly associated with a history of examinations at private clinics with $\mathrm{AOR}=4.51$ (95\%CI: 1.86-10.96).

\section{DISCUSSION}

Our results show that the importance of health service facilities were more likely to increase the selection of PHC or private clinics than individual practicing physicians. Whereas the capability of health providers was more likely to decrease the selection of private clinics compared to private practicing physicians, and the operational time of health services was more likely to increase the selection of private clinics compared to private practicing physicians. This shows the important role of structural factors in the selection of primary care in the JKN funding scheme. In the management activity scheme, namely input, process, and output, the input from health service management such as structural health management factors in primary care will affect the service process and subsequently will have an impact on the number of visits and ultimately satisfaction of participants in the JKN financing scheme. ${ }^{9}$

Our results show that the importance of facilities in the selection of primary care is similar to other studies in Indonesia such as studies conducted in the city of Semarang that reported a significant association between health facility completeness and selection of health care services. ${ }^{8}$ In addition to facility completeness, the results of this study also show the ability of health workers to relate to the selection of primary care, especially in the selection of private practicing physicians as primary care. The capability of doctors is an important consideration in the selection of health facilities given the effect on the success of treatment in the insurance participants and their families. ${ }^{6}$

Another structural factor, which is the operational time of health services is also associated with the selection of primary care. A study at the Pandanaran PHC also shows the importance of service time in the selection of health facilities. ${ }^{8}$ In other studies, operational time is analyzed separately in sub-domains such as variability of arrival and service time, patient and provider preferences, available information technology and staff experience in scheduling the services. ${ }^{11}$ Whereas in our study operational time of the services is examined in the form of respondents' perceptions about opening hours, health providers arrival schedules, service queue times, open and close times of the services and service times during holidays. Our study does not examine the information technology being used in the services. To anticipate operational time, one of the strategies that has been successfully implemented is to make appointments, especially appointments for services on holidays, the development of special strategies to anticipate these holidays affects patient decisions in selecting primary care. ${ }^{10}$

In addition to structural factors, there are respondents' characteristics that are significantly 
associated with primary care selection, which is the history of examinations with the preference to select private clinics as the primary care. This is likely related to the patient's relationship with the doctor and influences the patient's trust. ${ }^{12}$ Other studies also show that patient's close relationship with the private doctor is a single predictor of patient satisfaction after adjusted for the patient's and doctor's demographic characteristics, socioeconomic differences and health values. ${ }^{13}$

In our study, the demographic characteristics of patients did not have a significant relationship with primary care selection. This is likely because the demographic characteristics of respondents were not significantly different, while socioeconomic differences, health values and physician demographics were not examined because the focus of the study was only on structural factors perceived by respondents. A subsequent larger scale study can be directed to examine the role of patient's and doctor's demographics and primary care structural management in primary care selection so that intervention models can be developed to improve the quality of primary care and equitable distribution of JKN participants in registered PHCS.

Furthermore, in our study, distance to the health service was not related to primary care selection, which is likely because distance was not considered in primary care selection in urban areas, where the distribution of health facilities in urban areas was quite good. Different results were reported in a qualitative study in the United Kingdom in 2015 which showed that distance affects patient decisions in choosing health services and distance can make it easier to access health services in emergencies. ${ }^{14}$ Similar results were also reported in qualitative study in the United States in 2011 which showed that the public does not want to travel far to access health services. ${ }^{15}$

The implication of this study for BPJS policy is the importance of adding market-oriented criteria or reasons for JKN participants such as the completeness of facilities especially in comfort and support facilities, the capability of health providers especially in skill and hospitality and the operational time of health services in selecting primary care who want to collaborate with BPJS. This is believed to be able to encourage an even distribution of JKN participants who are registered at primary care.

The limitation in this study is that it is only conducted in Denpasar City with characteristics of urban areas and higher community demands compared to rural areas. Therefore, the results of the study may not be able to represent the condition of rural areas that have different demographic characteristics and perceptions of different structural factors so that they have different preferences in the selection of primary care.

\section{CONCLUSION}

Structural management of health services is significantly related to primary care selection. The structural factors for the management of health services are the completeness of health service facilities, operational time for health services, and the ability of health workers. Another significant factor is the history of examinations by primary care staff. Furthermore, the results of this study are expected to provide input for improving the quantity and quality in the provision of primary care so as to optimize the equal distribution of the number of participants in each primary care.

\section{ACKNOWLEDGEMENTS}

We would like to thank all respondents, the Head of West Denpasar Sub-district and the head of villages in West Denpasar for providing support during the data collection of this study.

\section{REFERENCES}

1. Thabrany H. Asuransi Kesehatan Nasional [National Health Insurance]. Jakarta: Rajawali Pers; 2013:124.

2. The President of The Republic of Indonesia. Peraturan Presiden Republik Indonesia Nomor 12 Tahun 2013 Tentang Jaminan Kesehatan [The President of The Republic of Indonesia Act No. 12 year 2013 on Health Insurance]. Jakarta; 2013:160.

3. Suandana IA. Faktor-faktor yang berhubungan dengan keinginan perpindahan fasilitas kesehatan tingkat pertama pada peserta JKN mandiri di Kota Denpasar Tahun 2017 (Mini Thesis) [Factors associated with switching primary care facilities among the national health insurance participants in Denpasar year 2017 (Mini thesis)]. Denpasar: Udayana University; 2017.

4. Hasan AG, Adisasmito WBB. Analisis kebijakan pemanfaatan dana kapitasi JKN pada FKTP puskesmas di Kabupaten Bogor tahun 2016 [Policy analysis on the utilization of national health insurance capitation at primary care in Bogor District year 2016]. Kebijakan Kesehatan Indonesia. 2017;06:127-137.

5. Foot C, Naylor C, Imison C. The quality of GP diagnosis and referral. London, UK: The King's Fund. England. 2010;1-79.

6. Victoor A, Delnoij DMJ, Friele RD, Rademakers JJ. Determinants of patient choice of healthcare providers: A scoping review. BMC Health Services Research. 2012;12(272):2-16.

7. Wun YT, Lam TP, Lam KF, Goldberg D, Li DKT, Yip KC. How do patients choose their doctors for primary care in a free market?. Journal of Evaluation in Clinical Practice. 2010;16(6):1215-1220.

8. Ratnasari C, Suharto S, Pramono D. Hubungan ketersediaan fasilitas, keramahan, lama pelayanan, usia dan tingkat pendidikan terhadap pemilihan tempat pemberi pelayanan kesehatan pada peserta Askes (Studi kasus di wilayah kerja Puskesmas Pandanaran Kota Semarang) (Skripsi) [The association between facilities, service time, age and level of education with the selection of primary care among the national health insurance participants (A case study at the area of Pandanaran Public Health Center, Semarang City) (Undergraduate thesis)]. Final report. Medical Faculty. Dipenogoro University; 2012. 
9. Pact Inc. Field guide for evaluation: How to develop an effective terms of reference. Washington DC. 2014;11-90.

10. Bornstein BH, Marcus D, Cassidy W. Choosing a doctor: An exploratory study of factors influencing patients' choice of a primary care doctor. Journal of Evaluation in Clinical Practice. 2001;6(3):255-262.

11. Gupta D, Denton B. Appointment scheduling in health care challenges and opportunities. Institute of Industrial Engineers Transactions. 2008;40(9):800-819.

12. Kao AC, Green DC, Davis NA, Koplan JP, Cleary PD. Patients' trust in their physicians: Effects of choice, continuity and payment method. Journal of General Internal Medicine. 1998;13(10):681-686.

13. Schmittdiel J, Selby JV, Grumbach K, Quesenberry CP, Jr. Choice of a personal physician and patient satisfaction in a health maintenance organization. Journal of the American Medical Association. 1997;278(19):1596-1599.
14. Blank L, Baxter S, Woods HB, Goyder E, Lee A, Payne N, et al. What is the evidence on interventions to manage referral from primary to specialist non-emergency care? A systematic review and logic model synthesis. Health Services and Delivery Research. 2015;03:1-430.

15. Brook RH. Is choice of physician and hospital an essential benefit?. Journal of the American Medical Association. 2011:305(02):195-196.

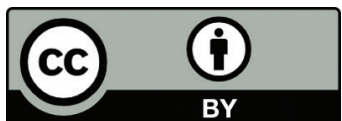

This work is licensed under a Creative Commons Attribution 